\title{
ANALYSIS OF FATTY ACID COMPOSITION OF MEAT PATES
}

\author{
O. Moskalyuk, I. Radzievska, A. Haschuk, L. Peshuk \\ National University of Food Technologies
}

\begin{tabular}{l}
\multicolumn{1}{c}{ Key words: } \\
Meat paste \\
Fatty acid composition \\
Shelf life \\
Health and preventive \\
nutrition \\
\hline \multicolumn{1}{c}{ Article history: } \\
Received 07.09.2018 \\
Received in revised form \\
05.10.2018 \\
Accepted 24.10.2018 \\
\hline
\end{tabular}

Corresponding author:

O. Moskalyuk

E-mail:

npnuht@ukr.net

\begin{abstract}
The article presents the results of studies of fatty acid composition and kinetics of fat oxidation in the process of storage of developed pates using fungal raw materials and phytocomplex of propagated grains of cereal crops. The high-resolution chromatography method established their group fatty acid composition and it was proved that the content of fatty acids in the trans-form is insignificant and does not exceed their background level for all samples of examined meat pates. It was found that the content of monounsaturated acids in developed paste is about $35 \%$, and saturated - only $23 \%$ in all investigated samples. Analyzing the content of PUFAs, it is important to note their stable high content in all four recipes, regardless of the type of added ingredients. However, the formula with mushroom raw material has the highest total PUFA content- $41.92 \%$ and at the same time the highest content of essential linolenic acid- $1.55 \%$.

To study the shelf life of developed meat pastes and check their stability, the oxidation of their lipid fraction was investigated. It has been established that pastes that were made using mushroom raw materials and phytocomplex of sprouted grains have both higher oxidative and commercially acceptable shelf life. The results of the study confirm the possibility of using mushroom raw materials and phytocomplex of sprouted grains in the production of health improvement and prophylactic paste.

Consequently, the creation of balanced formulations of meat pastes of high nutritional value with improved fatty acid composition can be considered as important directions in modern nutrition.
\end{abstract}

DOI: $10.24263 / 2225-2924-2018-24-5-24$

\section{АНАЛІЗ ЖИРНОКИСЛОТНОГО СКЛАДУ M'ЯСНИХ ПАШТЕTІВ}

\author{
О.Є. Москалюк, І.Г. Радзісвська, О.І. Гащук, Л.В. Пешук \\ Наиіональний університет харчових технологій
}

У статті наведено результати досліджень жирнокислотного складу й кінетики окиснення жиру в процесі зберігання розроблених паштетів з вико- 
ристанням грибної сировини та фітокомплексу пророщених зерен злакових культур. Методом хроматографії високороздільної здатності встановлено їх груповий жирнокислотний склад і доведено, що вміст жирних кислот у транс-формі є незначний і не перевищуе їх фонового рівня для всіх досліджуваних зразків м'ясних паштетів. Встановлено, що вміст мононенасичених кислот у розроблених паштетах становить близько $35 \%$, а насиченихлите 23\% в усіх досліджуваних зразках. Аналізуючи вміст ПНЖК, слід відмітити їх стабільно високий вміст в усіх чотирьох рецептурах незалежно від виду внесених компонентів. Проте рещептура з грибною сировиною відрізнясться найвищим загальним вмістом ПНЖК- 41,92\% та одночасно найвищим вмістом есениіальної ліноленової кислоти- $1,55 \%$.

Для вивчення термінів зберігання розроблених м'ясних паштетів і перевірки їх стабільності досліджували окислення їх ліпідної фракиії. Встановлено, щяо паштети, виготовлені з використанням грибної сировини та фітокомплексу пророщених зерен, володіють як більшою оксистабільностю, так $і$ комериійно прийнятними термінами придатності готової продукиії. Результати дослідження підтверджують можливість використання грибної сировини та фітокомплексу пророщених зерен у виробництві памтетів оздоровчо-профілактичного призначення.

Отже, створення збалансованих рецептур м'ясних паштетів підвищеної харчової иінності з поліпшеним жирнокислотним складом можна розглядати як важливий напрям у сучасному харчуванні.

Ключові слова: м'ясний паштет, жирнокислотний склад, термін зберігання, оздоровчо-профілактичне харчування.

Постановка проблеми. Біологічна цінність жирів визначається вмістом у ïx складі поліненасичених жирних кислот (ПНЖК). Для людини есенціальними жирними кислотами є лінолева C 18:2 і ліноленова С 18:3, які належать до незамінних складових харчування. Недостатнє надходження з їжею лінолевої та ліноленової кислот викликає порушення регуляції обмінних процесів у клітинних мембранах, а також у процесах утворення енергії в мітохондріях. ПНЖК сприяють прискоренню обміну холестеролу в організмі, уповільненню утворення атерогенних ліпопротеїдів низької щільності, зниженню синтезу тригліцеролів [1]. Зовнішнім проявом недостатності ПНЖК є зміни стану шкіри (сухість, лущення, екзема, гіперкератоз), підвищена сприйнятливість до ультрафіолетових променів, виникнення виразкових процесів слизової оболонки шлунку і дванадцятипалої кишки, карієсу зубів, артритів [2]. Останні досягнення науки глибше розкривають функції жирів в організмі людини i визначають зміни норм їх споживання з їжею.

Аналіз останніх досліджень і публікацій. Дослідження вчених показують, що одним із перспективних напрямків досліджень $є$ удосконалення технологій і розробка рецептур м'ясних продуктів із збалансованим жирнокислотним складом. Так, розробкою паштетів 3 додаванням вітамінізованих купажованих олій підвищеної біологічної цінності 3 метою поліпшення збалансованості амінокислотного та жирнокислотного складів займалися 
О.А. Топчій, Є.О. Котляр [3]. І.Г. Радзієвська, В.М. Пасічний. Вплив модифікованих жирів на показники біологічної ефективності напівфабрикатів 3 м'яса птиці досліджувався у [4].

Метою дослідження $є$ розроблення м'ясних паштетів 3 використанням грибної сировини та фітокомплексу пророщених зерен злакових культур зі збалансованим жирокислотним складом.

Викладення основних результатів дослідження. За результатами наукових досліджень, проведених на кафедрі технології м'яса і м'ясних продуктів в рамках держбюджетної тематики ДР № 0115U006059 «Наукове обгрунтування технології м'ясопродуктів нового покоління для оздоровчо-профілактичного харчування», були розроблені паштет «Грибний» 3 гливою в кількості $15 \%$, паштет «Особливий» 3 біомасою гливи звичайної Pleurotus ostreatus $3 \%$, паштет 3 фітокомплексом «СНОICЕ»-15\% [5; 6].

Для практичного регулювання фізіологічної цінності розроблених паштетів встановлено їх груповий жирнокислотний склад методом хроматографії високороздільної здатності. Результати дослідження наведено у табл. 1.

\section{Таблиия 1. Жирнокислотний склад досліджуваних паштетів}

\begin{tabular}{|c|c|c|c|c|}
\hline \multirow[b]{2}{*}{ Жирна кислота } & \multicolumn{4}{|c|}{ Жирнокислотний склад, \% суми жирних кислот } \\
\hline & Контроль & $\begin{array}{c}\text { № } 1 \\
\text { «Грибний» }\end{array}$ & $\begin{array}{c}\text { № } 2 \\
\text { «Особливий» }\end{array}$ & $\begin{array}{c}\text { № } 3 \\
\text { фітокомплекс } \\
\text { «СНОІСЕ» }\end{array}$ \\
\hline 1 & 2 & 3 & 4 & 5 \\
\hline C 8:0 & 0,01 & 0,01 & 0,01 & 0,01 \\
\hline C 10:0 Capric & 0,01 & 0,02 & 0,01 & 0,01 \\
\hline C 12:0 & 0,06 & 0,03 & 0,03 & 0,03 \\
\hline C $14: 0$ & 0,37 & 0,11 & 0,36 & 0,37 \\
\hline C 14:1 & 0,07 & 0,08 & 0,08 & 0,07 \\
\hline C 15:0 & 0,06 & 0,06 & 0,06 & 0,06 \\
\hline C 16:0 & 16,68 & 16,05 & 16,90 & 16,76 \\
\hline c9-C 16:1 & 0,31 & 0,47 & 0,32 & 0,30 \\
\hline c7-C 16:1 & 2,79 & 2,91 & 2,91 & 2,90 \\
\hline C 17:0 & 0,10 & 0,10 & 0,11 & 0,11 \\
\hline C $17: 1$ & 0,05 & 0,05 & 0,05 & 0,05 \\
\hline C 18:0 & 6,10 & 6,01 & 6,02 & 5,67 \\
\hline C 18:1w12t Petroselaidic & - & 0,15 & 0,15 & 0,14 \\
\hline c11-C 18:1 Vaccenic & 1,31 & 1,02 & 1,32 & 1,30 \\
\hline C 18:1w9c Oleic & 30,36 & 30,91 & 30,61 & 30,68 \\
\hline 9,12-t, c-C18:2 & 0,15 & 0,13 & - & 0,01 \\
\hline C 18:2w6c Linoleic & 37,42 & 37,47 & 37,27 & 37,88 \\
\hline C 20:0 & 0,15 & 0,15 & 0,15 & 0,15 \\
\hline C 20:1w9 & 0,07 & 0,07 & 0,07 & 0,07 \\
\hline C 20:1w11 & 0,30 & 0,31 & 0,30 & 0,30 \\
\hline C 18:3w6 & 0,23 & - & - & 0,19 \\
\hline C 18:3w3 a-Linolenic & 1,30 & 1,55 & 1,34 & 1,37 \\
\hline c9t11-C18:2 & 0,12 & 0,12 & 0,12 & - \\
\hline t10c12-C 18:2 & 0,01 & 0,01 & 0,01 & 0,01 \\
\hline 11,14- с C 20:2 & 0,22 & 0,14 & 0,22 & 0,20 \\
\hline
\end{tabular}




\begin{tabular}{|c|c|c|c|c|}
\hline \multicolumn{5}{|c|}{ Продовження табл. 1 } \\
\hline 1 & 2 & 3 & 4 & 5 \\
\hline C 20:3w6 & 0,17 & 0,17 & 0,17 & 0,15 \\
\hline C 20:4w6 Arachidonic & 1,17 & 1,08 & 1,08 & 0,84 \\
\hline C 20:5w3c & 0,02 & 0,02 & 0,02 & 0,07 \\
\hline C 22:0 & 0,17 & 0,17 & 0,17 & 0,18 \\
\hline C 22:5w3 & 0,06 & 0,06 & 0,07 & 0,05 \\
\hline C 23:0 & - & - & - & 0,01 \\
\hline C 24:0 & 0,06 & 0,06 & 0,06 & 0,06 \\
\hline C 24:1 & 0,02 & - & - & - \\
\hline C 22:6w3 & - & - & - & 0,04 \\
\hline Pa30M & 100,00 & 100,00 & 100,00 & 100,00 \\
\hline
\end{tabular}

3 даних табл. 1 видно, що жирова фракція розроблених паштетів містить усі групи жирних кислот, але їх вміст неоднаковий. Показано, що введення добавок грибної та рослинної сировини не викликає принципових змін вмісту окремих жирних кислот. Встановлено, що близько 2/3 загального вмісту жирних кислот належить до ненасичених, що $є$ позитивним фактором збалансованості раціону харчування.

Для забезпечення функціональних властивостей розроблених паштетів важливе значення має не лише кількісний, але й якісний склад жирів, особливо вміст поліненасичених жирних кислот з визначеним розміщенням подвійних зв'язків і цис-конфігурацією. Головні біологічні показники жирнокислотного складу досліджуваних паштетів наведено в табл. 2.

Таблиця 2. Біологічні показники жирнокислотниго складу

\begin{tabular}{|c|c|c|c|c|}
\hline \multirow{2}{*}{ Показник } & \multicolumn{4}{|c|}{ Зразок } \\
\cline { 2 - 5 } & Контроль & $\begin{array}{c}\text { № 1 } \\
\text { «Грибний» }\end{array}$ & № 2 «Особливий» & $\begin{array}{c}\text { № 3 } \\
\text { фітокомплекс } \\
\text { «СНОІСЕ» }\end{array}$ \\
\hline \multicolumn{5}{|c|}{ Співвідношення груп жирних кислот } \\
\hline НЖК & 23,78 & 23,35 & 23,88 & 23,41 \\
\hline МНЖК & 35,46 & 34,74 & 35,79 & 35,82 \\
\hline ПНЖК & 40,76 & 41,92 & 40,33 & 40,77 \\
\hline Лінолева С 18:2 & Вміст есенціальних кислот \\
\hline Ліноленова С 18:3 & 1,372 & 37,47 & 37,27 & 37,88 \\
\hline \multicolumn{7}{|c|}{ Вміст антихарчових жирних кислот } \\
\hline С 18:1 trans & 0,16 & 0,15 & 0,15 & 0,14 \\
\hline С 18:2 trans & 0,02 & 0,03 & 0,02 & 0,02 \\
\hline
\end{tabular}

Аналіз даних табл. 2 показав, що вміст мононенасичених кислот складає близько $35 \%$, а насичених - лише $23 \%$ в усіх досліджуваних зразках. Це підтверджує профілактичну спрямованість розроблених паштетів, оскільки 3 точки зору запобігання віковим хворобам вміст ненасичених складових жиру повинен бути якомога вищим. Аналізуючи вміст ПНЖК, слід відмітити їх стабільно високий вміст в усіх чотирьох рецептурах незалежно від виду внесених компонентів. Проте рецептура 3 паштету «Грибного» відрізняється найвищим загальним вмістом ПНЖК - 41,92\% та одночасно найвищим 
вмістом есенціальної ліноленової кислоти - 1,55\%. Це, очевидно, можна пояснити особливістю жирнокислотного складу внесеної добавки, оскільки в грибах міститься 1,3-2,7\% жиру, який на $67 \%$ складається 3 поліненасичених кислот. Встановлено, що вміст жирних кислот у трансформі є незначним і не перевищує їх фонового рівня для всіх досліджуваних рецептур.

Зважаючи на високий вміст легкоокиснюваних жирних кислот у складі досліджуваних паштетів, виникає необхідність перевірки їх стабільності протягом терміну зберігання. Для цього досліджували окислення їх ліпідної фракції розроблених паштетів.

Окиснювальна стабільність жирової фракції в цілому визначає стійкість харчового продукту до окиснення в процесі виробництва і зберігання. Стабільність продукту до окиснення впродовж терміну зберігання може бути представлена періодом, необхідним для досягнення критичного вмісту продуктів окиснення, незалежно від наявності змін сенсорних характеристик. Окиснення жиру також руйнує незамінні жирні кислоти, призводить до втрати харчової і біологічної цінності продукту та до утворення токсичних речовин. Це важливо для оцінки смакових і поживних властивостей, а також токсичності харчових продуктів.

Терміни придатності харчових продуктів визначаються граничними значеннями хімічних показників, регламентованих нормативною документацією i споживчими властивостями, в тому числі запахом і смаком. Залежно від умов зберігання та початкових властивостей продукту окиснення відбувається за різними механізмами. Окислювальна стабільність жиру у складі продукту залежить від його жирнокислотного складу, умов виробництва, впливу тепла i світла, концентрації і типу кисню, наявності вільних жирних кислот, моно- i дигліцеридів, металів змінної валентності, пероксидів, термічно окислених з'єднань, пігментів і антиоксидантів. Ці чинники взаємно впливають на процес окиснення і виділити їх індивідуальний ефект практично неможливо.

Кінетику окиснення жиру в процесі зберігання розроблених м'ясних паштетів характеризували величинами кислотного (КЧ) і пероксидного (ПЧ) чисел. Зразки продукції зберігали в незруйнованій упаковці за температури $+2^{\circ} \mathrm{C}$ за стандартної вологості повітря без доступу сонячного світла. Зміни якісних показників у відібраних пробах контролювали після екстракції жиру методом настоювання. Перебіг окиснення жиру в розроблених м'ясних паштетів вивчали через рівні проміжки часту протягом 8 діб.

Кислотне число характеризує глибину гідролітичного розпаду жиру та вказує на вміст вільних жирних кислот під час зберігання продукту (рис. 1).

3 рис. 1 видно, що зміна кислотного числа в процесі зберігання м'ясопродуктів описується рівнянням прямої. За час експерименту КЧ всіх досліджуваних зразків зростало, однак швидкість росту зразка-контролю була найвищою. Кислотні числа м'ясних паштетів за розробленими рецептурами монотонно збільшувались протягом 8 діб і зросли з $0,15-0,17$ до 0,40-0,50 мгКОН/г. Для харчових продуктів вищого гатунку цей показник нормується на рівні 1,0 мгКОН/г. Динаміка зміни кислотного числа розроблених рецептур м'ясних паштетів у процесі зберігання протягом 8 діб показала незначне зростання порівняно $з$ контролем, що $є$ підтвердженням ефективності підбору компо- 
нентів і заміни частини тваринних компонентів на грибну сировину чи фітокомплекс пророщених зерен.

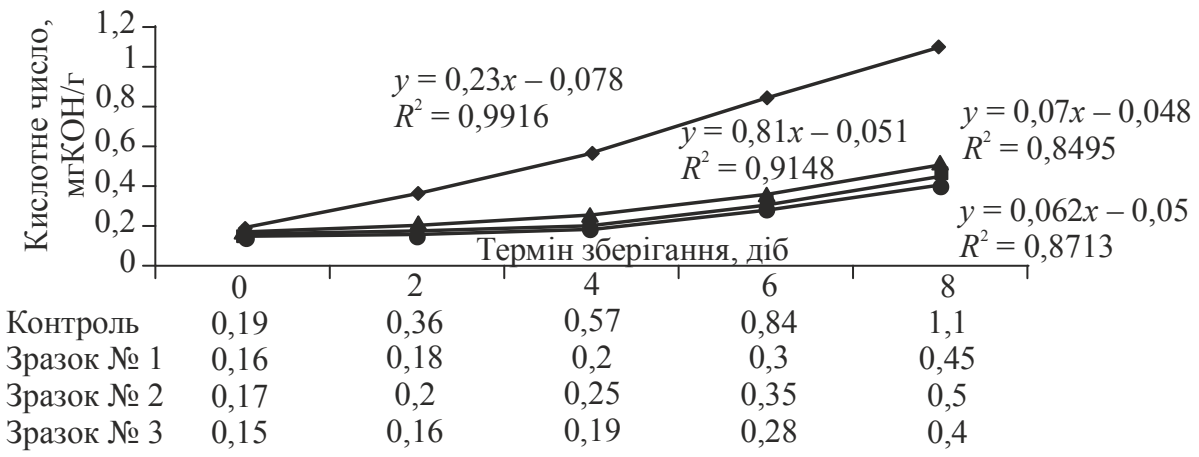

• Контроль - Вразок № 1 \З Зразок № 2 • Зразок № 3

Рис. 1. Зміна кислотного числа в процесі зберігання паштетів $\left(t+2{ }^{\circ} \mathrm{C}\right)$

Оскільки вільні жирні кислоти в жирах провокують процеси їх авто- i фотосенсибілізованого окиснення, вивчали перебіг окисних змін у розроблених паштетах за величиною пероксидного числа (рис. 2).

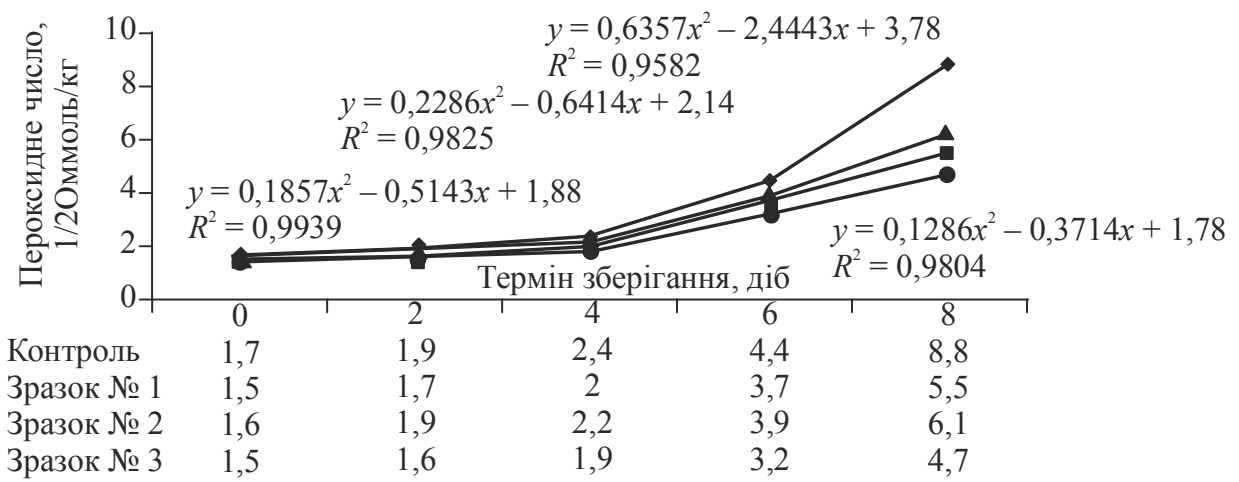

• Контроль - Вразок № $1 \quad$ \З Зразок № 2 • Зразок № 3

Рис. 2. Зміна пероксидного числа

в процесі зберігання паштетів пророщених зерен $\left(t+2{ }^{\circ} \mathrm{C}\right)$

3 графіків окиснення, наведених на рис. 2, видно, що перебіг окисних змін описується рівнянням поліноміальної кривої. Величина пероксидного чиста всіх зразків на початку зберігання $є$ незначною і становить $1,5-1,7$ 1/20ммоль/кг. Після періоду відносної стабільності, що тривав для всіх зразків чотири доби, швидкість накопичення продуктів окиснення різко зростає. На восьму добу зберігання найвище значення пероксидного числа зафіксоване в контрольному зразку на рівні $8,8 \frac{1}{2}{ }_{2}$ Оммоль/кг. Гранична величина цього показника становить 5 - $6 \frac{1}{2}$ Оммоль/кг при випуску 3 підприємства для різних продуктів. Серед розроблених рецептур достовірно нижча швидкість пероксидації встановлена в паштеті з фітокомплексом пророщених зерен — 4,7 1/2Оммоль/кг наприкінці експерименту. Серед рецептур з грибами слід відмітити порівняно вищу 
стійкість паштету з культивованою біомасою гливи Pleurotus ostreatus, ніж 3 гливами (5,5/20ммоль/кг проти $6,1 / 2$ Оммоль/кг на восьму добу зберігання). 3 огляду на це слід встановити граничний термін зберігання м'ясних паштетів за розробленими рецептурами не більше шести діб, коли величина ПЧ не перевищує норм, встановлених для доброякісної продукції.

Пояснення виявленої тенденції можна надати 3 точки зору впливу мінорних компонентів, які можуть виступати як прооксидантами, так і антиоксидантами. Зокрема, швидкість пероксидного окиснения суттєво залежить від швидкості утворення жирними кислотами алкільних радикалів, тобто визначається величиною КЧ в кожній окремій точці контролю. Швидке зростання величини КЧ в зразку-контролі певним чином пояснює високу швидкість накопичення в ньому пероксидів. Уповільнення накопичення пероксидів у жировій фракції паштету з фітокомплексом пророщених зерен, імовірно, слід пояснити антиоксидантними властивостями природних сполук (феноли, токоферол, вищі спирти), які нині активно вивчаються.

\section{Висновки}

За результатами дослідження отримали паштети для оздоровчо-профілактичного харчування, в яких вміст мононенасичених кислот становить близько $35 \%$, а насичених - лише $23 \%$. Аналізуючи вміст ПНЖК, відмічено їх стабільно високий вміст в усіх рецептурах незалежно від виду внесених компонентів. Проте рецептура 3 грибною сировиною відрізняється найвищим загальним вмістом ПНЖК- 41,92\% та одночасно найвищим вмістом есенціальної ліноленової кислоти - 1,55\%.

Паштети 3 фітокомплексом пророщених зерен володіють як більшою оксистабільністю, так і комерційно прийнятними термінами придатності готової продукції. Для зниження окиснюваності розроблених м'ясних паштетів слід знижувати температуру зберігання, виключати вплив світла і повітря, використовувати відповідні концентрації антиоксидантів.

\section{Лiтература}

1. Knapp H.R. Physiological and biochemical effects of n-3 fatty asids in man. Essential Fatty Acids and Eicosanoids / Eds A. Sinclair, R. Gibson. Champaign: AOCS Publications, 2003. P. $330-333$.

2. Жиры, их пищевая и биологическая ценность URL: https://www.pitportal.ru/samples_docs/gigiena_pitaniya/6034.html.

3. Котляр С.О., Топчій О.А. Розробка рецептур м'ясних паштетів з використанням білково-жирових емульсій на основі вітамінізованих купажованих рослинних олій. Науковий вісник ЛНУВМБТ імені С.З. Гжицького. 2017. Т. 19. № 75. С. 89-96.

4. Шведюк Д.А., Пасічний В.М., Радзієвська І.Г.Вплив модифікованих жирів на показники біологічної ефективності напівфабрикатів 3 м'яса птиці. Аграрна наука та харчові технології. 2017. Випуск 3(97). С. 249-257.

5. Москалюк О.Е., Пешук Л.В., Гащук О.I., Чернюшок О.А. Разработка мясного паштета повышенной биологической ценности. Пищевая промыциленность: наука и технологии. г. Минск, Республика Беларусь. 2017. № 4(38). С. 9-13.

6. Москалюк О.Є. Дослідження термінів зберігання м'ясних паштетів функціонального призначення. Наукові праці Наиіонального університету харчових технологій. Київ: НУХТ, 2018 р. Том 24, № 2. С. 225-231. 